\title{
11
}

\section{Common property management of highly migratory fish stocks: tuna in the Pacific}

\section{Janaline Oh}

The purpose of this chapter is to consider possibilities for sustainable management of highly migratory tuna fisheries in the Central and Western Pacific-specifically the area covered by the 200 nautical mile exclusive economic zones (EEZs) of South Pacific Forum member countries and contiguous high seas areas. The chapter adopts a definition of common property as property that is controlled collectively by a defined group of decision-making units, rather than as no property or open access. Sustainability is defined as management that will enable long-term harvesting of the fisheries resources at their maximum sustainable yield. This chapter does not attempt to consider issues of biological diversity nor of the social aspects of sustainable development.

Changes in international law over the past decade have affected the international legal and political environment for fisheries management. I do not enter into the debate over the role of fisheries in economic development for Pacific island countries, other than to acknowledge that the development aspirations of those island countries have a strong bearing on the way in which they are likely to approach fisheries management and access issues. The interactions discussed in the chapter refer to government to government negotiations on international fisheries issues. Although inshore 
communities are important in decisions relating to fisheries management, for the deep sea tuna fisheries considered in this chapter, it is governments (represented by their officials) who undertake negotiations and reach agreements which must then be implemented domestically. Finally, the chapter concludes that a common property approach is the only feasible way of developing a conservation and management regime for highly migratory fish stocks in the Pacific, and that such an approach entails an essentially political process.

\section{The nature of the fishery: framing the problem}

The tuna resources of the Central and Western Pacific, which covers the zones of the independent Pacific island countries, represent one of the few remaining internationally significant tuna fisheries. The principal tuna species are skipjack (Katsuwonus pelamis), yellowfin (Thunnus albacares), bigeye (Thunnus obesus) and albacore (Thunnus alalunga). The region supplies over 50 per cent of the world's canning tuna (Maxwell and Owen 1994). These fisheries also provide a significant foreign exchange and government revenue earner for Pacific island countries, particularly the Micronesian countries which have few other resources available for development. The economic benefits to island countries come mainly in the form of licence fees for access from distant water fishing nations under bilateral or multilateral agreements. Some benefits are generated through domestic fisheries and onshore processing and associated activities, or through employment of Pacific island nationals on deep sea tuna boats. Atoll countries, in particular Kiribati, Federated States of Micronesia and Marshall Islands, aspire to develop their domestic fisheries to increase the economic benefits, including in terms of employment, and to reduce reliance on licence fees from distant water fleets. This affects their approach to access to fisheries within their fishing zones, and to regional fisheries management.

The tuna stocks of the South Pacific region are in good health, with scientific assessments indicating that harvesting remains within sustainable levels, although some uncertainty exists for bigeye tuna stocks. This contrasts with a number of significant collapses of fish stocks in other regions of the world, for instance the Grand Banks cod off the coast of Canada. The reasons stem from the low rates of harvesting of tuna in the region, well within the sustainable harvesting range, the rapid growth and strong recruitment for the tropical tuna 
species (compared with temperate tuna such as southern bluefin tuna-Thunnus maccoyii), and the region's relative isolation from major markets, which reduces the rate of return from fishing operations.

The Central and Western Pacific tuna fisheries present an opportunity for coastal states in the region to demonstrate that sustainable management of highly migratory fish stocks is possible. An important factor in the outcome will be the ability of coastal states to cooperate with distant water fishing nations within a management regime.

\section{Property rights: some definitions}

Before going further, it would be useful to state some definitions underlying the arguments of this chapter. First, this chapter adopts the view that property rights do not exist objectively, but rely upon a prior social contract whereby others recognise one's right to that property (Bromley 1991:6). Second, it takes Bromley's definition that a 'right' is 'the capacity to call upon the collective to stand behind one's claim to a benefit stream' (1991:15).

In other words, the property is not the object (in this case, the fish), but rather the benefit stream arising from the resource. This is important in the context of tuna fisheries because the coastal state's right to charge foreign fishing vessels to fish in exclusive economic zones was not recognised by distant water fishing nations until a relatively late stage in the negotiations of the United Nations Convention on the Law of the Sea (UNCLOS). The definition of property as a benefit stream is significant to the distribution of benefits from a fishery that spans the fishing zones of several coastal states, and further includes distant water fishing fleets. This is relevant to the Central and Western Pacific where most fishing operators are from distant water fishing nations rather than coastal states in the region.

Bromley identifies four types of property rights within these broad definitions: individual property rights, where one clearly defined entity (a person or a corporation) holds the right; state property rights, where a government or other administrative authority holds the right on behalf of society; common property rights, where a clearly defined group of decision-makers holds the rights and acts collectively in the exercise of those rights; and open access or no property rights (1991:23). Bromley then notes that different types of property rights also entail responsibilities. This is important for fisheries access under UNCLOS which requires coastal states that cannot exploit their 
fisheries resources to the full total allowable catch to allow others to fish in their zones (United Nations 1983: Article 62)-although this has not been fully applied in practice. It is also relevant to fisheries management when one looks at those parts of UNCLOS that require fishing states (both coastal states and those fishing on the high seas) to undertake measures for the conservation and management of a resource. The Law of the Sea Convention does not itself define property rights explicitly, but Bromley's definitions describe the assumptions of property rights that underlie those parts of the Convention that relate to fisheries exploitation, conservation, and management.

Commercial fisheries management within individual countries has tended to rely on a mixture of state property rights and individual property rights, where states have powers over licensing or total catch quotas, and individuals can hold fishing rights through tradeable licences or individual transferable quotas. Fisheries management involving more than one country, especially where the fishery also operates on the high seas, has tended to bear more relation to a common property regime, where the governments of the countries involved have acted collectively or through negotiation to manage the resource (Tsamenyi and Kaye 1994 review some of the existing international agreements for cooperative fisheries management). In this case, the individual governments behave in a way analogous to community elders managing a village resource: the collective decision-making body (whose membership is clearly defined) exercises control over the resource with respect to individual units (in this case fishing operators). This has been the case in the Central and Western Pacific.

\section{Access and management ${ }^{1}$}

At this point it is worth distinguishing between access to fisheries and management of fisheries. A management regime must include controlling effort within a fishery, which may also involve limiting access. Access relates to who is allowed to participate in the fishery, whereas management seeks to ensure that those who are participating behave in a way that is consistent with the long-term sustainability of the resource. Indeed, when one talks about management of the fish resource, one is really talking about management of those who are exploiting that resource: we are not managing the fish, but rather the fishing operators (Bromley 1991:21).

The principal means of controlling access to stocks used by individual countries, or collectively by groups of countries, has been 
through licensing in domestic fisheries or negotiating fleet access by foreign operators. Access is generally based on: considerations of sustainability (are there enough fish?); distribution of benefits (capturing the resource rent); and allocation of quotas (where necessary). Under the Convention for the Conservation of Southern Bluefin Tuna, for instance, there is a provision for catch quotas to be allocated between the fleets of the Parties, currently Australia, Japan and New Zealand (DFAT 1993: Article 8[3]).

Within the context of a particular management regime, the use of economic instruments has been adopted in some countries to maximise the economic efficiency of the fishery. In particular, the use of individual transferable quotas within a total allowable catch, has been shown to have met general criteria for economic efficiency (Ministry of Fisheries 1996). Duncan and Temu (1996) have proposed the auctioning of tradeable licences in Pacific island countries. There is still some debate within fisheries management circles as to whether output controls such as catch quotas or input controls such as limits on vessel numbers (for instance through licensing) or gear restrictions are more effective in ensuring fisheries management. Input controls seek to control catch level by placing limits on effort, while output controls place limits on catch. Under both systems, limits on effort that compromise biological imperatives are either prescribed or proscribed.

A key part of this debate is the effectiveness of monitoring and enforcement. While some argue that output controls are a more reliable means of controlling stock levels, they also raise significant potential compliance problems, such as high grading (where lower quality or smaller fish are discarded, but nonetheless killed), which can have detrimental effects on the status of the fish stocks. They also require significant resources for monitoring, control and surveillance. Input controls such as limits on vessel numbers (for example, through licensing) are the alternative means of controlling the exploitation of the resource, and can place overall physical constraints on the harvest - without the incentive to high grade, there is a physical limit to the amount of fish that one vessel can catch within a given amount of time. Input controls are, however, vulnerable to changes in technology. More efficient gear or fishing techniques can extend the physical constraints on a vessel's catch per unit of effort.

Management, however, involves considerably more than control of effort. Regardless of whether one opts for input rather than output controls, there remains a requirement for significantly better regional 
surveillance and compliance enforcement than is currently available. While Forum member countries are exploring the possibility of applying a regional vessel monitoring system, which will enable both location monitoring and the entry of catch and effort data, there are still significant issues to be negotiated, such as the application of the vessel monitoring system on the high seas.

Other issues important for management include the provision by vessels of verifiable catch and effort data, which is essential for stock assessment and thus for an understanding of whether the stocks are being over-fished; the capacity to enforce management measures; and the role of flag states in controlling the activities of their nationals fishing in other countries' fishing zones or on the high seas.

Procedures for the peaceful settlement of disputes are also important both for the confidence of fishing operators that their vessels will not be subject to arbitrary harrassment, and for the assurance of coastal states that they can apply legal measures to protect the resource from illegal behaviour on the part of fishing operators.

\section{The international legal environment}

Common property management of fisheries in an international context has been developed and codified in international law through the United Nations Conferences on the Law of the Sea, the third of which culminated in 1982 with the adoption of the Law of the Sea Convention. UNCLOS now provides support under international law for coastal state claims to the benefits from fishing zones beyond their territorial seas, and an agreed legal framework for common property management of international fisheries. The Law of the Sea negotiations, which took well over a decade to complete, covered a range of issues from boundaries to innocent passage, and from fisheries management to sea-bed mining, in recognition of their interdependence (United Nations 1983). The focus on conservation and management of fisheries resources acknowledged that countries could not individually manage fish stocks that either straddled fishing zones or the high seas, nor stocks that migrated beyond individual fishing zones (Doulman 1995). UNCLOS did not come into force until 1994, twelve years after its conclusion and opening for signature. Partly because the Convention was adopted by consensus, however, its provisions were recognised internationally well before it came into force, and it has long been established in customary international law. 
Two aspects of the Law of the Sea that are pertinent to this chapter are the definition of an exclusive economic zone (EEZ) not more than 200 nautical miles (nm) from a coastal State's territorial sea baseline (United Nations 1983: Articles 55-9), and provisions for the management of ocean resources for conservation and optimum utilisation, both within EEZs (United Nations 1983: Articles 61-7) and on the high seas (United Nations 1983: Articles 116-20). All South Pacific Forum member countries have now declared either exclusive economic zones or fishing zones at $200 \mathrm{~nm}$ from their baselines. The combined fishing zones of Forum countries (including eastern Australia) amounts to around 20 million sq $\mathrm{km}$, or around 80 per cent of the area serviced by the FFA, the rest being high seas (Maxwell and Owen 1994:2). All Forum countries except Kiribati and Palau are signatories to UNCLOS (or have acceded) and most have ratified (United Nations 1996).

UNCLOS has two important consequences for the (mostly) newly independent island countries of the Pacific. Firstly, it confers upon coastal states a property right to fisheries resources within their EEZs. UNCLOS provides only qualified fishing rights both within EEZs and on the high seas. Article 56 defines for coastal states 'sovereign rights' (but not 'sovereignty') and jurisdiction with regard to installations, marine scientific research and protection of the marine environment, but it also stipulates that

[i]n exercising its rights and performing its duties under this Convention in the exclusive economic zone, the coastal state shall have due regard to the rights and duties of other states and shall act in a manner compatible with the provisions of this Convention (United Nations 1983: Article 56[2]).

Similarly, all states have a right to fish on the high seas, but only subject to the rights and duties as well as the interests of coastal states' (United Nations 1983: Article 116).

Secondly, it confers upon coastal states and fishing states the associated responsibility to manage marine resources for conservation and optimum utilisation. UNCLOS sets out detailed requirements for coastal states to conserve fisheries resources through the determination of allowable catch on the basis of the best available scientific advice (Article 61), to allow others to fish in their EEZs if their nationals lack the capacity to harvest the entire allowable catch (Article 62) and to cooperate with others in managing shared and straddling stocks (Article 63) and highly migratory species (Article 64). States fishing on the high seas are moreover required to take measures to conserve 
fisheries resources (Articles 117 and 119), and to cooperate in the conservation and management of high seas resources (Article 118).

The provisions of UNCLOS, and particularly Articles 63, 64 and 117-19, are important for the Pacific islands region. All four of the major tuna species harvested in the region are listed in Annex I of UNCLOS as highly migratory species. Under UNCLOS and its associated Implementing Agreement (UN 1995) there is an international legal requirement on Parties to cooperate in the conservation and optimum utilisation of the stocks. The Implementing Agreement, which was opened for signature in December 1995, and has been ratified by the United States, Saint Lucia and Tonga, details the application of those Articles of UNCLOS (63, 64 and 117-19) that relate to management of straddling and highly migratory fish stocks, in particular in relation to the respective responsibilities of coastal States and distant water fishing nations (Doulman 1995). It also requires the application of the precautionary principle, where a conservative approach must be taken in the absence of conclusive scientific evidence (United Nations 1995: Article 6).

Many specific measures for fisheries management have been incorporated into the UN Implementing Agreement, which provides for the establishment of limit and target reference points to be applied to catch quotas, according to the best estimates of maximum sustainable yield (Annex II); provision of catch and effort data and verification of that data (Annex I); elaboration of the responsibilities of flag states to control the operations of their fleets on the high seas (Articles 18 and 19); surveillance and enforcement procedures both within EEZs and on the high seas (Articles 19-23); and procedures for the peaceful settlement of disputes between countries (Articles 27-32).

The Implementing Agreement further provides that, where a regional or sub-regional organisation or arrangement has been established for conservation and management of straddling or highly migratory fish stocks

[o]nly those states which are members of such an organization or participants in such an arrangement, or which agree to apply the conservation and management measures established by such organization or arrangement, shall have access to the fishery resources to which those measures apply (United Nations 1995: Article 8(4)).

The capacity to exclude from fishing those who refuse to apply measures agreed within a regional conservation and management arrangement is a significant step in minimising the possible third state 
problems in regional fisheries management identified by Tsamenyi and Kaye (1994). It is also significant in further limiting the traditional Grotian notion of the freedom of the seas: while the Law of the Sea Convention limits this by qualifying the right of states to fish on the high seas (Tsamenyi and Kaye 1994), the UN Implementing Agreement further suggests that states can be excluded from fishing in certain high seas areas if they are unwilling to comply with conservation and management measures that others have agreed to apply in those waters. It also raises questions about the application of the Vienna Convention on the Law of Treaties which provides that states are not bound by obligations they have not signed onto (DFAT 1974: Article 34). It is not clear whether a non-Party to the UN Implementing Agreement can be excluded from high seas fisheries for which a conservation and management arrangement has been agreed.

\section{Existing regional arrangements for management}

Concerns about the management of the highly migratory fish stocks in the Pacific are not new to the region. South Pacific Forum members ${ }^{2}$ have a long history of cooperation in the management of their fisheries resources, based on common property concepts. The Forum Fisheries Agency (FFA), comprising a Committee and Secretariat, was established in 1979 when its Convention was opened for signature at the 1979 South Pacific Forum (OPA 1995: Vol I, 1979 Forum Communiqué). The Committee was 'to promote intra-regional co-ordination and cooperation' in inter alia fisheries management policies, interactions with distant water fishing nations, and surveillance and enforcement (FFA 1979: Article V). Since then, FFA member countries have put in place a number of cooperative arrangements affecting regional fisheries management. The Nauru Agreement Concerning Cooperation in the Management of Fisheries of Common Concern was adopted in 1982, and the Parties to the Nauru Agreement ${ }^{3}$ have since formed an influential sub-regional grouping within FFA on fisheries access and management issues.

In 1987, the US government signed a treaty with FFA member countries governing fisheries access for the region. This ended a decade-long dispute between the United States and FFA members over fisheries access, where the United States had refused to recognise fishing zones beyond territorial seas (Bergin 1994). The Treaty provides for significant management controls, including the presence 
of observers, paid for by vessel operators, catch and effort data provision both within fishing zones and on contiguous high seas, and cooperative enforcement procedures. The Treaty also provides for a flat rate access fee and a limit on vessel numbers (FFA 1994: Articles 35 and Annex I). The Treaty was seen as a significant step towards regional fisheries management and similar arrangements were subsequently sought with other distant water fishing nations (OPA 1995: Vol II, 1994 Forum Communiqué). Since the Treaty was concluded, however, no multilateral agreement on access has been concluded with another distant water fishing nation, although negotiations are underway between some FFA member countries and the Taiwan Deep Sea Tuna Boatowners' Association over access to the albacore longline fishery (FFA 1996).

Other legal instruments that have been adopted in the region relating to fisheries management include the Palau Arrangement for the Management of the Western Pacific Purse Seine Fishery (1992), which provides for cooperative action on limiting the number of licences for foreign purse seine vessels. Although the licences are then made available for domestic operators, it acts as a limit on total vessel numbers as domestic fishing operators are not in a position to take up the additional licences. Limiting the number of licences available to foreign fishing vessels was also intended to increase competition for those licences to raise the licence fees. The number of licences allowed under the Palau Arrangement is higher than the existing number of operative licences, but the Arrangement's provisions remain generally constraining on foreign fishing effort within member countries' EEZs. The Niue Treaty on Cooperation in Fisheries Surveillance and Law Enforcement in the South Pacific Region provides a head agreement under which member countries can enter into bilateral subsidiary agreements to share surveillance and enforcement assets, such as patrol boats and personnel. Tuvalu and Tonga are the only two countries that have concluded a subsidiary agreement.

A significant development in regional fisheries management was the adoption in 1991 of the Minimum Terms and Conditions for Fisheries Access (MTCs). These provide for the positioning of observers on boats at the expense of vessel operators, catch and effort data provision (including for fishing on the high seas where that was part of a trip that included fishing within EEZs), prohibition of transhipment at sea, and registration on the Regional Register of Fishing Vessels held by the FFA Secretariat. The Regional Register 
gives status of 'good standing' that can be withdrawn for serious transgressions, whereby a vessel without 'good standing' will not be allowed to fish in the zone of any FFA member country (FFA 1993). FFA members have gradually incorporated the MTCs into bilateral access arrangements. Although they have no separate standing under international law, the MTCs and the Regional Register have contributed to management through regional cooperation. The ban on transhipment at sea, which took effect in mid-1993, led to a significant improvement in catch reporting and compliance, and the risk of losing 'good standing' on the Regional Register has encouraged transgressing vessel operators to settle disputes expeditiously and out of court (Bergin 1994).

\section{Sustainable management for the future?}

FFA member countries have acknowledged the need for a cooperative approach to future management arrangements for regional fisheries (FFC 1996). The 27th South Pacific Forum in Majuro agreed to convene in mid-1997 a second High Level Multilateral Consultation on the Conservation and Management of Fisheries Resources of the Central and Western Pacific, involving coastal states and territories in the region and distant water fishing nations (South Pacific Forum 1996). The first High Level Multilateral Conference on South Pacific Tuna Fisheries was held in Honiara in December 1994 (FFC 1996).

The highly migratory nature of the resource and its importance to island countries proscribes consideration of regional fisheries management in isolation from its political and social context. Treatment of Central and Western Pacific tuna fisheries under a system of individual property rights (as separate fishing zones governed by countries acting independently) is unrealistic because of the highly migratory nature of the stocks. Furthermore, the coming into force of the Law of the Sea Convention and the adoption of the UN Implementing Agreement creates an international legal obligation on coastal states in the region to cooperate with each other and other fishing nations in fisheries management. On the other hand, the kind of open-access regime where no property rights are established, such as occurred in international waters (beyond territorial seas) prior to the Law of the Sea, is inimical to the sustainability of the stocks. Although the creation of property rights can assist the exploitation of a terrestrial resource (implying that an absence of property rights can impede 
exploitation), the experience of fisheries has been that unrestricted access has led to resource depletion. This threat is increasing in the Central and Western Pacific where distant water fleets are expanding rapidly without explicit management constraints. The common property management approach that has been taken to date in the Forum would thus seem to be the only one feasible: indeed, this is why collective management approaches to international fisheries issues have been pursued all over the world.

The island countries of the Forum region are by no means uniform in their fisheries interests. The tiny atoll states of Micronesia, and Tuvalu, have enormous fishing zones but little else in terms of potential foreign exchange earnings and development opportunities. The larger Melanesian countries have significant fisheries resources (from time to time, depending on the migration of the stocks), which are important sources of income, notwithstanding other development options and a better natural resource endowment. In contrast, most of the Polynesian countries do not have substantial pelagic fisheries resources: whereas over 70 per cent of reported catches of the northerly yellowfin and skipjack tuna in the region are caught within EEZs, the more southerly albacore and bigeye fisheries involve a higher proportion of high seas activity. The significant differences in fisheries endowments and the relative importance of fisheries to different island economies has an obvious influence on the approaches that island countries take to regional fisheries management and access arrangements, and will have a bearing on the cohesiveness of their approach to fisheries negotiations with distant water fishing nations.

Despite commitments in the Forum in favour of multilateral access arrangements, the benefits from a US Treaty-style arrangement with other distant water fishing nations are not uniformly distributed between island countries. The US Treaty fees are distributed according to a formula by which all Pacific island parties (including Australia and New Zealand) receive an equal share of 15 per cent of the fee, with the residual (after deduction of administrative costs) divided up between countries according to the proportion of catch taken in their zones. Thus, those countries with little or no catch taken in their zones are in effect subsidised by the others. The resource-rich Parties to the Nauru Agreement countries might then have some justification in feeling that they could negotiate higher fees bilaterally than through a similar arrangement. This is particularly the case for the Asian distant water fishing nations, which have already made clear that, 
unlike the United States, they will not subsidise their fleets to boost licence fees. On the other hand, the less resource-rich FFA member countries argue with justification that the generous fees obtained through the US Treaty would not have been forthcoming without their cooperation in negotiating the agreement, and that collective bargaining by all FFA member countries has brought concrete dividends in the form of higher fees that have benefited all members, and particularly those with significant catches in their fishing zones.

Notwithstanding their differing fisheries interests, which might affect their individual attitudes towards access arrangements with distant water fishing nations and their aspirations to develop their own domestic fishing industries, Forum island countries have a common interest in the conservation and sustainable management of regional fisheries. The challenge before them now is to find similar common interests with distant water fishing nations and other coastal states that share the fisheries resources, and to negotiate a management regime that ensures the long-term viability of the resource while still meeting their economic needs and development aspirations.

Recent changes in international law, with the conclusion and coming into force of the Law of the Sea Convention and the adoption in December 1995 of the UN Implementing Agreement, lend considerably more support now in international law for collective management between countries of highly migratory resources. Associated with the support afforded in international law comes an increased obligation on Forum island countries to cooperate with distant water fishing nations and non-Forum coastal states and territories in fisheries conservation and management: in effect to negotiate a common property management regime that extends the existing cooperation between coastal states in the region.

\section{Implications for common property}

The process that Forum leaders have committed themselves to in calling the second High Level Multilateral Consultation on regional fisheries conservation and management will provide another test of the ability of countries with widely varying interests, endowments, and levels of development to cooperate in the common property management of a resource that is important to all players. It is a classic example of a common property situation, where the decision-making 
units (the governments of the countries involved) interact at a level of at least nominal equality. The developing coastal states in the region are small and have little international political clout, but have a history of collective action and a right acknowledged in international law to the benefits of the rich fisheries resources within their exclusive economic zones. For some, the resources represent the principal opportunity to achieve their development aspirations. By contrast, the distant water fishing nations include the two largest economies in the world who have considerable international political and economic weight-including the capacity to use their aid funds as leverage-but who nonetheless view the resource as significant to at least certain influential sections of their societies. It is a situation in which significant negotiating power resides with the politically and economically weak island countries in the form of rights to the benefits of their exclusive economic zones. The test lies in the ability of all parties to ensure that the strong interests apparent on all sides in the resource work towards a collective management outcome rather than dissipating into a conflict that could threaten the future of the fisheries.

The advent of the UN Implementing Agreement is also important in altering the boundaries of the resource. ${ }^{4}$ Whereas the Law of the Sea Convention is based on the individual property rights created for countries through the declaration of exclusive economic zones, the Implementing Agreement blurs that distinction in its application. The Agreement is to apply to 'the conservation and management of straddling fish stocks and highly migratory fish stocks beyond areas under national jurisdiction' (Article 3), except that the general principles of the Agreement (Article 5), the provisions relating to the application of the precautionary approach (Article 6) and to the compatibility of conservation and management measures (Article 7) are to be applied by coastal states within areas of national jurisdiction.

The provisions for compatibility outlined in Article 7 arose from the recognition by the UN Conference on Straddling Fish Stocks and Highly Migratory Fish Stocks that national and international measures for conservation and management needed to be compatible in order to be effective (Doulman 1995:9). From a common property perspective, however, the effect of this eminently sensible management approach has been to soften the boundaries between the individual property rights exercised within EEZs ('sovereign rights' as characterised in UNCLOS and the Implementing Agreement) and the high seas areas where a common property regime is to apply. 
The compatibility provisions have the additional effect of potentially strengthening the position of coastal states in determining common management measures. The first criterion for compatibility required states to

take into account the conservation and management measures adopted and applied in accordance with article 61 of the (Law of the Sea) Convention in respect of the same stocks by coastal states within areas under national jurisdiction and ensure that measures established in respect of such stocks for the high seas do not undermine the effectiveness of such measures (United Nations 1995: Article 7(2a)).

This implies that, if coastal states apply conservation and management measures in accordance with the relevant provisions of UNCLOS (Article 61), they are in a strong position under international law to require distant water fishing nations to apply compatible measures under a common property regime on the high seas, or at least to apply measures that do not undermine the management regimes that apply within their EEZs. In the Pacific, this could have practical implications for the outcomes of negotiations on regional management measures for tuna stocks.

\section{Conclusion}

The capture of economic rent by individual coastal states within the context of an agreed conservation and management regime is within the bounds of those states' sovereign rights to benefit from the resource, and the mechanisms for maximising that benefit can be developed unilaterally. The most difficult task facing coastal states in the South Pacific Forum region is to agree on a management regime whereby distant water fishing nations (and their fleets) bear their share of the responsibilities of conservation, and in which catch allocation and access to the resource is structured in a way that both maximises the benefits to island countries and distributes those benefits in an acceptably equitable way. These issues are not unique to the Pacific, but are being played out in fisheries forums in the Indian Ocean and the Antarctic. The experiences of each set of negotiations will, over time, inform and influence each other in providing precedents and models for common management of common resources. 


\section{Notes}

The views expressed in this chapter are those of the author and not necessarily those of the Department of Foreign Affairs and Trade, Canberra.

1. I am grateful to Jonathon Barrington of the Commonwealth Department of Primary Industries and Energy, and to Ian Cartwright and Tony Kingston of the Forum Fisheries Agency for elaborating the fisheries management concepts in this section.

2. South Pacific Forum member countries are Australia, Cook Islands, Federated States of Micronesia, Fiji, Kiribati, Marshall Islands, Nauru, New Zealand, Niue, Palau, Papua New Guinea, Solomon Islands, Tonga, Tuvalu, Vanuatu and Western Samoa.

3. Parties to the Nauru Agreement are Federated States of Micronesia, Kiribati, Marshall Islands, Nauru, Palau, Papua New Guinea, Solomon Islands and Tuvalu.

4. I am grateful to Transform Aqorau of the University of Wollongong for alerting me to the implications of these provisions of the UN Implementing Agreement for common property.

\section{References}

Bergin, Anthony, 1994. 'Political and Legal Control Over Marine Living Resources-recent developments in South Pacific distant water fishing', International Journal of Marine and Coastal Law 9(3): 289-309.

Bromley, Daniel W., 1991. Environment and Economy: property rights and public policy, Blackwell, Cambridge, Mass.

Department of Foreign Affairs and Trade (DFAT), 1974. Vienna Convention on the Law of Treaties 1969, Australian Treaty Series 1974, 2, DFAT, Canberra.

- 1993. Convention for the Conservation of Southern Bluefin Tuna 1993, DFAT, Canberra.

Doulman, David J., 1995. Structure and Process of the 1993-1995 United Nations Conference on Straddling Fish Stocks and Highly Migratory Fish Stocks, FAO Fisheries Circular 898, Food and Agriculture Organization of the United Nations, Rome.

Ron Duncan and Ila Temu, Trade, investment and sustainable development of natural resources in the Pacific: the case of fish and timber, paper presented to the Economic and Social Commission for Asia and the Pacific Expert Group Meeting on Enhancing Cooperation in Trade and Investment Between Pacific island Countries and Economies of East and South East Asia in the 1990s, Port Vila, Vanuatu, July, 8-12, 1996, unpublished. 
Forum Fisheries Agency (FFA), 1979. South Pacific Forum Fisheries Agency Convention, FFA, Honiara.

- 1993. United Nations Conference on Straddling Fish Stocks and Highly Migratory Fish Stocks: New York, 3-20 July 1993, Forum Fisheries Agency, Honiara, unpublished.

1994. Treaty on Fisheries Between the Governments of Certain Pacific Island States and the Government of the United States of America (1994 Edition), Forum Fisheries Agency, Honiara.

_ 1996. Forum Fisheries Agency: Report of the Director 1996, Forum Fisheries Agency, Honiara.

Forum Fisheries Committee, 22 February 1996. Forum Fisheries Committee Meets in Fiji and Appoints New Deputy Director, press release.

Maxwell, J.G.H. and A.D. Owen, 1994. South Pacific Tuna Fisheries Study, AusAID, Canberra.

Ministry of Fisheries, 1996. OECD Committee for Fisheries: fisheries management techniques: country report: New Zealand, Wellington.

Office of Pacific Island Affairs (OPA), 1995. South Pacific Forum Communiqués, Vols 1 (1971-90) and 2 (1991-95), DFAT, Canberra.

South Pacific Forum, 5 September 1996. Twenty-Seventh South Pacific Forum Communique.

Tsamenyi, Martin and Stephen Kaye, 1994. 'The Southern Bluefin Tuna Convention: the management of highly migratory species and third States', Maritime Studies 75:1-13.

United Nations, 1983. The Law of the Sea: United Nations Convention on the Law of the Sea, United Nations, New York.

United Nations, 1995. Agreement for the Implementation of the Provisions of the United Nations Convention on the Law of the Sea of 10 December 1982 relating to the Conservation and Management of Straddling Fish Stocks and Highly Migratory Fish Stocks, United Nations, New York.

United Nations, 1996. Information on the Law of the Sea, Internet site http://www.un.org/Depts, Division for Ocean Affairs and the Law of the Sea, Office of Legal Affairs, New York. 